\title{
Kesan Ekstrak Akueus Rosel (Hibiscus sabdariffa Linn.) terhadap Sperma dan Testis Tikus Diadministrasi Nikotin
}

(Effects of Aqueous Extract of Roselle (Hibiscus sabdariffa Linn.) on Sperm and Testis in Rat-administered Nicotine)

\author{
IZATUS SHIMA TAIB, SiTI BALKIS BUDIN*, MAIZATUL NADHIRAH ISMAIL, \\ SATIRAH ZAINALABIDIN \& JAMALUDIN MOHAMED
}

\begin{abstract}
ABSTRAK
Penghasilan radikal bebas oleh nikotin dikaitkan dengan kerosakan sistem pembiakan lelaki terutamanya sperma dan testis. Penggunaan rawatan yang berasaskan herba seperti Hibiscus sabdariffa Linn. (HSE) kian meningkat disebabkan kandungan antioksida semula jadi yang tinggi. Oleh itu, kajian ini dijalankan untuk mengkaji kesan ekstrak akueus HSE terhadap kualiti sperma dan tekanan oksidatif testis tikus yang diadministrasi nikotin. Sejumlah 21 ekor tikus jantan Sprague-Dawley dibahagikan secara rawak kepada tiga kumpulan iaitu kumpulan kawalan, nikotin dan nikotin+HSE. Nikotin disuntik secara intraperitoneum pada dos $0.6 \mathrm{mg} / \mathrm{kg}$ berat badan manakala HSE diberikan pada dos $100 \mathrm{mg} /$ $\mathrm{kg}$ berat badan secara paksaan oral sebelum administrasi nikotin pada setiap hari selama 21 hari berturut-turut. Hasil kajian menunjukkan bilangan, motiliti dan viabiliti sperma lebih tinggi secara signifikan $(\mathrm{p}<0.05)$ manakala peratus ketaknormalan morfologi sperma lebih rendah secara signifikan $(\mathrm{p}<0.05)$ bagi pada kumpulan nikotin $+H S E$ berbanding kumpulan nikotin. Sementara itu berlakunya penurunan aras malondialdehid (MDA) dan peningkatan aras glutation terturun (GSH) secara signifikan ( $<<0.05)$ bagi kumpulan nikotin+HSE berbanding kumpulan nikotin . Pemerhatian histologi mendapati HSE berpotensi melindungi morfologi testis tikus aruhan nikotin. Kesimpulannya, kajian ini menunjukkan bahawa pemberian suplemen ekstrak HSE berpotensi mencegah kerosakan sperma dan testis akibat administrasi nikotin.
\end{abstract}

Kata kunci: Antioksida; reproduktif; rokok; rosel; tekanan oksidatif

\section{ABSTRACT}

The generation of free radicals from nicotine is associated with reproductive damage especially on sperms and testis. The usage of treatment based on herbs such as Hibiscus sabdariffa Linn. (HSE) is gradually increased due to the high content of natural antioxidant. Therefore, this study was aimed to investigate the effects of extract aqueus HSE on sperms and testis in rat-administered nicotine. A total of 21 male Sprague Dawley rats were divided into three groups which were the control, nicotine and nicotine + HSE group. The nicotine was injected via intraperitoneum at the dose of $0.6 \mathrm{mg} / \mathrm{kg}$ body weight, while the HSE was given at the dose of $100 \mathrm{mg} / \mathrm{kg}$ body weight, orally before the nicotine administration for 21 censequtive days. The findings showed significantly $(\mathrm{p}<0.05)$ increased of sperm count, motility and viability while significantly $(\mathrm{p}<0.05)$ decreased of percentage of abnormal sperm morphology in the nicotine + HSE group compared with the nicotine group. Furthermore, the level of malondialdehyde $(M D A)$ reduced significantly $(\mathrm{p}<0.05)$ and the level of glutathione $(G S H)$ increased significantly $(\mathrm{p}<0.05)$ in the nicotine + HSE group compared with the nicotine group. Histology study showed the potential of HSE in protecting the testis morphological alteration induced by nicotine. In conclusion, supplementation of HSE has the potential to prevent sperm and testis damage induced by nicotine.

Keywords: Antioxidant; oxidative stress; reproductive; roselle; cigarette

\section{PENGENALAN}

Penggunaan rokok dan pelbagai produk tembakau semakin meningkat dalam kalangan negara membangun dan sedang membangun (WHO 2010a). Nikotin adalah bahan alkaloid terbanyak yang dikesan dalam tembakau dan asap rokok serta merupakan bahan yang menyebabkan ketagihan melampau pada perokok (Campain 2004). Ia boleh meresap ke dalam tubuh melalui kulit dan saluran respiratori dan dioksidakan dengan cepat di hepar kepada metabolit utamanya iaitu kotinin (Tundulawessa et al. 2010).
Nikotin telah dilaporkan memberi impak negatif terhadap status kesihatan dunia dan telah dikenal pasti sebagai salah satu faktor yang menyumbang kepada penyakit kardiovaskular serta kanser sistem penghadaman (Polyzos et al. 2009). Pelbagai kajian terdahulu menunjukkan pendedahan nikotin secara berulangan telah menyebabkan peningkatan penghasilan spesies oksigen reaktif (ROS) (Dhouib et al. 2015; Mosbah et al. 2015). Malah nikotin juga menyebabkan kesan genotoksik, imunotoksik serta kerosakan pada sistem reproduktif (Polyzos et al. 2009). Kajian terdahulu 
mendapati nikotin menyebabkan penurunan kepada kadar persenyawaan (Steinman et al. 2001), isi padu dan kepekatan semen (Trummer et al. 2002), motiliti dan viabiliti sperma (Lado-Abeal \& Norman 2002) serta menyebabkan perubahan corak pergerakan sperma (Zhang et al. 2000).

Hibiscus sabdariffa Linn. (HSE) adalah pokok renek dikotiledon daripada keluarga Malvaceae dan dikenali sebagai Rosel (Ross 1999). HSE berpotensi sebagai agen anti-hipertensi (Mozaffari-Khosravi et al. 2009), antidiabetes (Idris et al. 2012), anti-hiperkolesterolemik (Lin et al. 2007) dan anti-obesiti (Alarcon-Aguilar et al. 2007). Selain itu, ekstrak kaliks kering HSE terbukti menunjukkan aktiviti antioksida yang tinggi (Hirunpanich et al. 2006). Sehingga kini, kajian mengenai kesan HSE terhadap kerosakan sistem reproduktif jantan aruhan nikotin masih kurang dilakukan. Oleh itu, kajian ini dijalankan untuk melihat kesan perlindungan ekstrak akueus HSE terhadap kerosakan sperma dan testis pada tikus diadministrasi nikotin.

\section{BAHAN DAN KAEDAH}

\section{BAHAN KIMIA}

Nikotin dibeli daripada Merck, Darmstadt, Jerman. Bahan kimia yang lain dibeli daripada Sigma Chemicals Co., St. Louis, Amerika Syarikat kecuali formaldehid, paraffin, xilena dan asid asetik glasial diperoleh dari ICN Biochemicals, Jepun.

\section{PENYEDIAAN EKSTRAK AKUEUS KALIKS ROSEL}

Penyediaan ekstrak ini berdasarkan kaedah Idris et al. (2012). Kaliks rosel (yang diketahui beratnya) dibersih, dipotong halus dan dikisar bersama air suling. Larutan ini kemudiannya dipanas sehingga mendidih, kemudian disejukkan dan ditapis menggunakan cheese cloth. Larutan campuran yang terhasil disimpan dalam keadaan kedap cahaya pada suhu $4^{\circ} \mathrm{C}$. Sebanyak $20 \%$ maltodekstrin ditambah ke dalam larutan sebelum proses semburan kering dilakukan menggunakan mesin semburan kering Mini Spray Dryer B-290 (Buchi, Swirtzeland). Suhu mesin semburan kering ditetapkan pada $180^{\circ} \mathrm{C}$ dan $117^{\circ} \mathrm{C}$ masing-masing pada saluran masuk dan keluar dengan kadar suapan pam pada $5 \mathrm{rpm}$.

\section{REKA BENTUK KAJIAN}

Kajian ini menggunakan tikus jantan dewasa SpragueDawley yang diperoleh daripada Unit Sumber Haiwan Makmal, Fakulti Perubatan, Universiti Kebangsaan Malaysia, Kuala Lumpur, Malaysia dengan purata berat dalam lingkungan 230-250 g. Tikus diletakkan di dalam sangkar plastik (polypropylene) pada suhu $27 \pm 2^{\circ} \mathrm{C}$ dengan kitaran 12-jam-cahaya/12-jam-gelap. Tikus diberikan makanan dan minuman piawai tanpa had sepanjang kajian. Kajian ini dijalankan berdasarkan syarat dan piawai pengendalian haiwan kajian yang telah diluluskan oleh Jawatankuasa Etika Penggunaan Haiwan (UKMAEC) dengan nombor etika: FSKB/BIOMED/2013/BALKIS/25SEPT./539-OCT.-2013.FEB.2014.

Tikus kajian dibahagikan kepada tiga kumpulan dengan tujuh ekor setiap kumpulan. Kumpulan kawalan - disuntik salin normal $(0.5 \mathrm{~mL} /$ tikus $)$ secara intraperitoneum (i.p); kumpulan nikotin - disuntik nikotin pada dos sebanyak $0.6 \mathrm{mg} / \mathrm{kg}$ berat badan (bb) secara i.p. (Toklu et al. 2010) dan kumpulan nikotin+HSE -disuntik nikotin $(0.6 \mathrm{mg} / \mathrm{kg} \mathrm{bb})$ selepas pemberian HSE pada dos $100 \mathrm{mg} / \mathrm{kg}$ bb secara oral paksa. Dos $100 \mathrm{mg} / \mathrm{kg}$ HSE digunakan dalam kajian ini adalah berdasarkan kajian yang dijalankan oleh Idris et al. (2012) yang mendapati dos $100 \mathrm{mg} / \mathrm{kg}$ HSE berpotensi melindungi testis tikus diabetes dan tidak menyebabkan sebarang kesan toksik pada tikus jantan yang normal. Suntikan salin normal, nikotin dan pemberian HSE dilakukan setiap hari selama 21 hari (Helen et al. 2000). Pada akhir kajian, tikus dikorbankan untuk mendapatkan sperma dan testis. Sperma diambil daripada kauda epididimis untuk analisis ciri sperma manakala testis untuk analisis tekanan oksidatif dan histologi.

\section{PERSEDIAAN SAMPEL KAJIAN}

Kedua-dua kauda kanan dan kiri epididimis dicincang dalam $2 \mathrm{~mL}$ larutan penimbal Hank's bergaram (HBSS) pada suhu $37^{\circ} \mathrm{C}$. Larutan tersebut diempar pada kelajuan $1000 \mathrm{rpm}$ selama tiga minit bagi mendapatkan sperma. Testis kanan dihomogenat dalam $1.15 \%$ larutan potasium klorida dengan nisbah $5 \mathrm{~mL} / \mathrm{g}$ (v/w) dalam keadaan berais. Kemudian, larutan homogenat testis dihomogenkan menggunakan alat homogenat Ultra Turrax T25 dan diempar pada kelajuan $8000 \mathrm{rpm}$ selama 20 min pada suhu $4^{\circ} \mathrm{C}$. Supernatan diambil dan disimpan pada suhu $-80^{\circ} \mathrm{C}$ sebelum dianalsis. Testis kiri pula dimasukkan ke dalam larutan formalin $10 \%$ untuk analisis histologi.

\section{ANALISIS CIRI SPERMA}

Penentuan ciri sperma tikus kajian adalah berdasarkan kaedah WHO (2010b) dengan sedikit modifikasi. Bilangan sperma dikira menggunakan Makler Counting Chamber. Pengiraan bilangan sperma dilakukan sebanyak tiga kali dan hasil dinyatakan dalam bentuk ( $\left.\times 10^{6} \mathrm{sel}\right)$. Dengan menggunakan alatan yang sama, sebanyak 200 sperma dikira bagi penentuan peratus motiliti sperma. Bilangan motiliti sperma dikira dan dinyatakan dalam bentuk peratus.

Untuk analisis viabiliti sperma, suspensi sperma ditambahkan ke dalam $1 \%$ eosin dan dibiarkan selama 30 s. Selepas itu, larutan $10 \%$ nigrosin dititiskan ke dalam larutan dan apusan tebal dilakukan. Sebanyak 200 ekor sperma dikira bagi penentuan bilangan sperma yang hidup dan keputusan dinyatakan dalam bentuk peratus viabiliti. 
Sementara itu, analisis morfologi sperma dilakukan dengan menggunakan pewarnaan eosin Y $2 \%$. Supernatan sperma dicampurkan dengan larutan eosin Y $2 \%$, dibiarkan selama 30 min dan apusan nipis dijalankan. Sebanyak 200 sperma dikira untuk penentuan perubahan morfologi dan keputusan dinyatakan dalam bentuk peratus.

\section{ANALISIS TEKANAN OKSIDATIF TESTIS}

Analisis status antioksida iaitu superoksida dismutase (SOD) dan glutation terturun (GSH) serta lipid peroksidasi iaitu malondialdehid (MDA) ditentukan menggunakan larutan homogenat testis. Aktiviti SOD ditentukan menggunakan kaedah Beyer dan Fridovich (1987) manakala aras GSH ditentukan menggunakan kaedah Ellman (1959). Penentuan aras MDA pula ditentukan menggunakan kaedah Stocks dan Dormandy (1971).

\section{PEMERHATIAN HISTOLOGI TESTIS}

Tisu testis yang telah difiksasi dengan formalin diproses berdasarkan kaedah histologi piawai. Blok tisu parafin dipotong dengan ketebalan $5 \mu \mathrm{m}$ dan diwarnakan dengan pewarnaan hematoksilin dan eosin (H\&E). Perubahan morfologi dilihat menggunakan mikroskop cahaya di bawah pembesaran $\times 10$ dan $\times 40$.

\section{ANALISIS STATISTIK}

Analisis statistik dilakukan dengan menggunakan Pakej Statistik untuk Sains Sosial (SPSS) versi 21.0. Ujian Shapiro-Wilk digunakan untuk menentukan taburan kehomogenan varians. Jika data yang diperoleh didapati mempunyai taburan normal, maka ujian ANOVA satu hala digunakan untuk membandingkan nilai purata antara kumpulan kumpulan kajian. Hasil kajian dinyatakan dalam bentuk purata \pm purata ralat piawai (SEM) dan nilai dianggap signifikan pada aras keertian $p<0.05$.

\section{KEPUTUSAN}

\section{ANALISIS CIRI SPERMA}

Berdasarkan Jadual 1, didapati bilangan sperma kumpulan nikotin+HSE adalah lebih tinggi secara signifikan $(p<0.05)$ berbanding kumpulan kawalan dan nikotin. Malah pemberian HSE pada tikus nikotin+HSE meningkatkan purata peratusan motiliti dan viabiliti sperma secara signifikan $(p<0.05)$ berbanding kumpulan nikotin. Selain itu, pemberian HSE pada tikus nikotin+HSE juga menurunkan purata peratusan ketaknormalan morfologi sperma secara signifikan $(p<0.05)$ berbanding kumpulan nikotin. Morfologi kepala sperma yang normal dan tidak normal ditunjukkan dalam Rajah 1.

JADUAL 1. Perbandingan purata ciri sperma tikus kumpulan kajian. Nilai dinyatakan dalam bentuk purata \pm SEM. ${ }^{a}$ berbeza secara signifikan berbanding kumpulan kawalan; bberbeza secara signifikan berbanding kumpulan nikotin

\begin{tabular}{lccc}
\hline Parameter & Kawalan & Nikotin & Nikotin + HSE \\
\hline Bilangan sperma $\left(\times 10^{6}\right.$ sel) & $21.74 \pm 2.17$ & $20.63 \pm 2.95$ & $37.89 \pm 3.54^{\mathrm{a}, \mathrm{b}}$ \\
Motiliti sperma $(\%)$ & $63.29 \pm 3.62$ & $34.79 \pm 7.05^{\mathrm{a}}$ & $66.00 \pm 3.11^{\mathrm{b}}$ \\
Viabiliti sperma $(\%)$ & $70.74 \pm 1.73$ & $26.60 \pm 0.92^{\mathrm{a}}$ & $73.54 \pm 2.74^{\mathrm{b}}$ \\
Ketaknormalan morfologi sperma $(\%)$ & $23.96 \pm 0.83$ & $33.52 \pm 1.39^{\mathrm{a}}$ & $18.97 \pm 0.76^{\mathrm{b}}$ \\
\hline
\end{tabular}
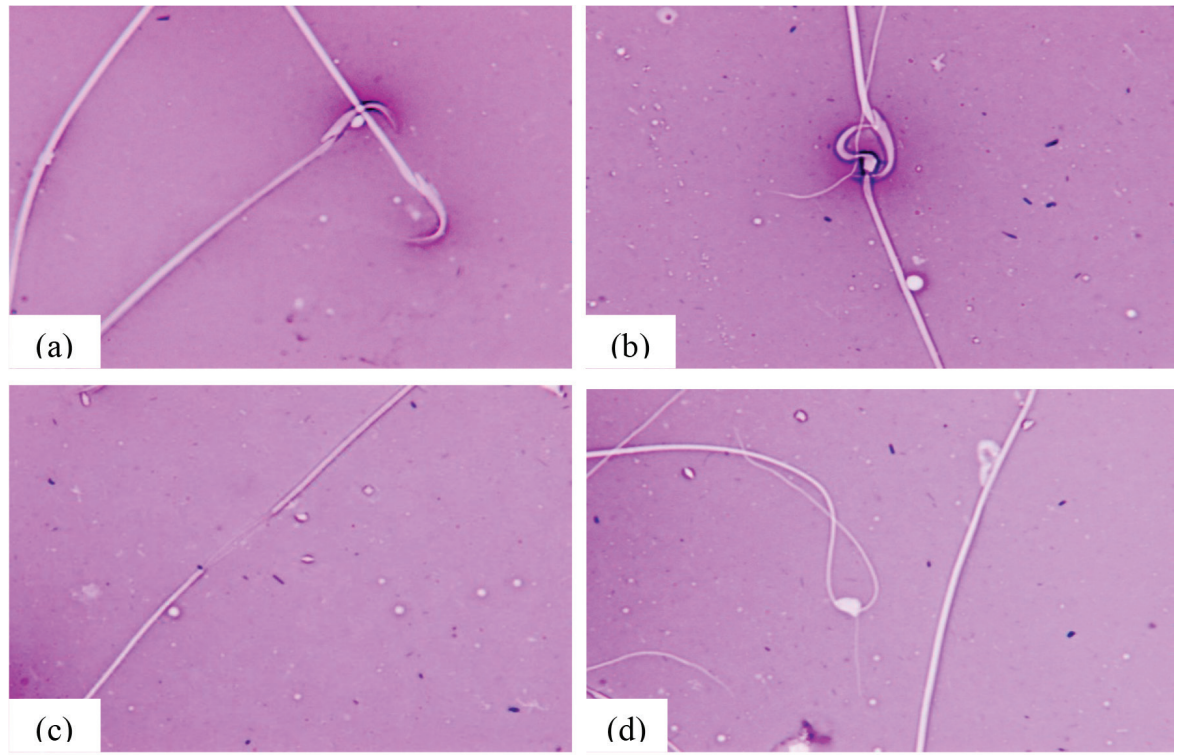

RAJAH 1. Morfologi sperma tikus kajian, a) morfologi normal sperma; b-d) ketaknormalan sperma; b) kepala separa normal; c) ekor terputus dan d) ekor bergelung 


\section{ANALISIS TEKANAN OKSIDATIF}

Jadual 2 menunjukkan tiada perbezaan yang signifikan bagi purata aktiviti enzim SOD testis antara semua kumpulan kajian. Walau bagaimanapun, hasil kajian mendapati purata aras MDA testis pada kumpulan nikotin+HSE adalah lebih rendah dan aras GSH adalah lebih tinggi secara signifikan $(p<0.05)$ berbanding kumpulan kawalan dan nikotin (Jadual 2).

\section{PEMERHATIAN HISTOLOGI TESTIS}

Struktur tubul seminiferus tikus kawalan menunjukkan morfologi yang normal yang dicirikan dengan kehadiran sel germa dan sperma di dalam lumen tubul. Tubul seminiferus ini diasingkan antara satu sama lain oleh ruang interstitial (Rajah 2(a)). Rajah 2(b) pula menunjukkan kehadiran sel germa yang melapisi tubul seminiferus dengan sperma yang padat. Tikus kumpulan nikotin pula menunjukkan morfologi tubul seminiferus yang tidak normal dengan kehadiran sel germa di dalam lumen tubul. Ketaknormalan ini dikenali sebagai sloughing (Rajah 2(c)). Bilangan sperma yang kurang padat juga diperhatikan di dalam lumen tubul seminiferus tikus nikotin serta berlakunya penyusutan lapisan sel germa (Rajah 2(d)). Sementara itu, tikus nikotin dengan suplementasi HSE menunjukkan morfologi tubul seminiferus yang normal seperti kumpulan kawalan yang dicirikan dengan kehadiran sperma yang padat serta lapisan sel germa yang normal (Rajah 2(e) dan 2(f)).

\section{PERBINCANGAN}

Kajian ini menggunakan nikotin pada dos $0.6 \mathrm{mg} / \mathrm{kg}$ dan diberi setiap hari untuk selama 21 hari berturut-turut. Dos nikotin yang dipilih pada kajian ini menyerupai aras kotinin plasma pada perokok ringan. Hasil kajian mendapati pemberian nikotin telah menyebabkan penurunan kualiti sperma dengan menurunkan peratus motiliti, viabiliti dan meningkatkan peratus ketidaknormalan morfologi sperma.

Menurut kajian terdahulu, administrasi nikotin menyebabkan penurunan aktiviti antioksida iaitu SOD, katalase serta glutation reduktase serta peningkatan aras radikal bebas. Penurunan kualiti sperma telah dilaporkan berlaku pada manusia yang terdedah kepada nikotin dan dipercayai berlaku akibat peningkatan aras radikal bebas dan penurunan aktiviti antioksida (Trummer et al. 2002;
Wong et al. 2000). Radikal bebas akan menyerang sperma yang kaya dengan asid lemak politaktepu yang kaya pada membrannya dan menyebabkan kerosakan oksidatif. Selain menjadi sasaran radikal bebas, penurunan kualiti sperma juga disebabkan oleh penurunan aras hormon testosteron yang penting dalam proses spermatogenesis (Trummer et al. 2002).

Pemberian sumber semula jadi yang kaya dengan antioksida dipercayai mampu meningkatkan kualiti sperma. Mohamed et al. (2012) mendapati suplementasi madu yang kaya dengan vitamin $\mathrm{C}$ telah menyebabkan perubahan yang positif terhadap kualiti sperma pada tikus yang didedahkan asap rokok selama 13 minggu. Hasil kajian ini mendapati pemberian ekstrak akueus HSE berupaya mencegah kerosakan sperma pada tikus yang diadministrasi nikotin. Didapati kualiti sperma pada tikus yang diberi ekstrak akues HSE menunjukkan peningkatan motiliti dan viabiliti dan penurunan perubahan morfologi sperma yang terjejas akibat nikotin. Hasil kajian ini selari dengan kajian oleh Idris et al. (2012) yang mendapati pemberian ekstrak akueus HSE berpotensi memelihara kualiti sperma pada tikus diabetes melalui mekanisme antioksidan serta potensinya dalam meningkatkan aras hormon androgen.

Penurunan kualiti sperma turut dibuktikan dengan perubahan histopatologi testis tikus aruhan nikotin yang dicirikan dengan pengurangan bilangan spermatozoa dalam lumen tubul seminiferus. Penurunan bilangan sel Sertoli dan sel Leydig di dalam testis tikus kajian aruhan nikotin menunjukkan berlakunya gangguan penghasilan hormon androgen iaitu testosteron. Ini secara tidak langsung menyebabkan gangguan pada proses spermatogenesis (Mosbah et al. 2015). Suplementasi HSE pada tikus yang diberi nikotin berpotensi meningkatkan bilangan sel spermatozoa. Hasil kajian ini menyokong kajian oleh Syazana et al. (2011) mendapati tikus yang diberi suplementasi madu mempunyai spermatozoa yang lebih padat. Selain itu, menurut Mohamed et al. (2012), suplementasi madu berpotensi meningkatkan proses spermatogenesis pada tikus normal. Ini membuktikan bahan yang kaya dengan antioksida berpotensi melindungi testis daripada mengalami kerosakan oksidatif serta berupaya meningkatkan penghasilan sperma (Mohamed et al. 2012; Syazana et al. 2011).

Pendedahan nikotin secara berulangan telah dilaporkan menyebabkan berlakunya kerosakan oksidatif pada testis dan paru-paru tikus akibat peningkatan penghasilan ROS

JADUAL 2. Perbandingan tekanan oksidatif testis tikus kumpulan kajian

\begin{tabular}{lccc}
\hline Parameter & Kawalan & Nikotin & Nikotin + HSE \\
\hline SOD (U/min/mg protein) & $2.07 \pm 0.06$ & $2.07 \pm 0.08$ & $2.09 \pm 0.05$ \\
GSH (mmol/mg protein) & $112.84 \pm 9.30$ & $112.24 \pm 5.36$ & $139.93 \pm 13.81^{\mathrm{a}, \mathrm{b}}$ \\
MDA (nmol/mg protein) & $1.17 \pm 0.05$ & $1.31 \pm 0.11$ & $0.89 \pm 0.12^{\mathrm{a}, \mathrm{b}}$ \\
\hline
\end{tabular}

Nilai dinyatakan dalam bentuk purata \pm SEM. aberbeza secara signifikan berbanding kumpulan kawalan; berbeza secara signifikan berbanding kumpulan nikotin 

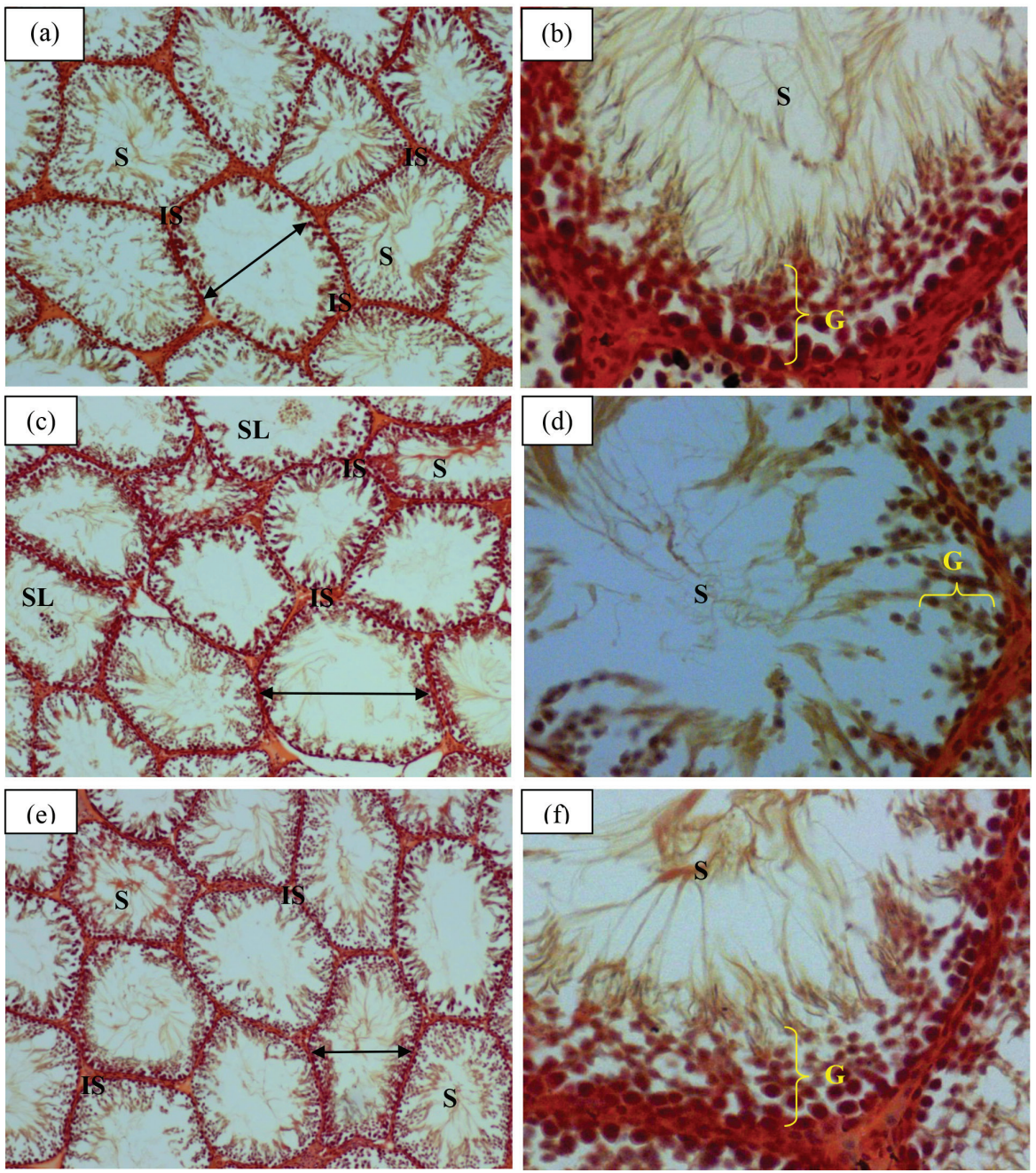

RAJAH 2. Morfologi testis tikus kajian pada pembesaran $(\times 10)(a, c$ dan e) dan $(\times 40)(b, d$ dan $f)(P e w a r n a a n ~ H \& E)$, (a) Tikus kawalan menunjukkan tubul seminiferus $(\leftrightarrow$ ) yang normal dengan kehadiran sperma (S) di dalam lumen tubul serta ruang interstitial (IS) yang kecil, (b) Morfologi tubul seminiferus tikus kawalan yang dilapisi dengan sel germa (G) dan kehadiran sperma (S) yang padat, (c) Penurunan bilangan sperma di dalam lumen tubul seminiferus tikus nikotin serta kehadiran tubul seminiferous 'sloughing' (SL),

(d) Bilangan sperma (S) yang sedikit dan penipisan lapisan sel germa serta (e) dan (f) Morfologi tubul seminiferus tikus nikotin+HSE menunjukkan morfologi normal dengan kehadiran sperma yang padat di dalam tubul dan lapisan sel germa yang normal

(Dhouib et al. 2015; Mosbah et al. 2015). Pemberian nikotin secara i.p. selama 2 bulan pada dos $1 \mathrm{mg} / \mathrm{kg}$ telah menyebabkan berlakunya kerosakan oksidatif pada sistem reproduktif tikus kajian (Mosbah et al. 2015). Pemberian HSE dalam kajian ini berpotensi meningkatkan aras antioksida serta menurunkan peroksidasi lipid pada testis tikus aruhan nikotin. Kajian oleh Olusola dan Adekunle (2011) mendapati kandungan antosianin di dalam ekstrak kaliks HSE mampu memberikan kesan perlindungan terhadap kerosakan oksidatif akibat pendedahan terhadap agen xenobiotik.

\section{KESIMPULAN}

Ekstrak akueus rosel berpotensi memberikan kesan perlindungan pada sperma dan testis melalui peningkatan kualiti sperma serta mengurangkan tekanan oksidatif dan melindungi morfologi testis tikus aruhan nikotin.

\section{PENGHARGAAN}

Penulis ingin memberikan penghargaan kepada Universiti Kebangsaan Malaysia serta Kementerian Pengajian Tinggi (KPT), Malaysia yang telah memberikan Geran Penyelidikan GUP-2013-008 untuk membiayai penyelidikan ini.

\section{RUJUKAN}

Alarcon-Aguilar, F.J., Zamilpa, A., Perez-Garcia, D., AlmanzaPerez, J.C., Romero-Nunez, E., Efrain, A., CamposSepulveda, Laura I., Vazquez-Carrillo \& Roman-Ramos, R. 2007. Effect of Hibiscus sabdariffa on obesity in MSG mice. Journal of Ethnopharmacology 114: 66-71.

Beyer, W. \& Fridovich, I. 1987. Assaying for superoxide dismutase activity: Some large consequences of minor changes in conditions. Analytical Biochemistry 161: 559- 566.

Campain, J.A. 2004. Nicotine: Potentially a multifuntional carcinogen. Toxicology Science 79: 1-3.

Dhouib, H., Jallouli, M., Draief, M., Bouraoui, S. \& El-Fazaa, S. 2015. Oxidative damage and histopathological changes in 
lung of rat chronically exposed to nicotine alone or associated to ethanol. Pathologie Biologie 63: 258-267.

Ellman, G. 1959. Tissue sulfhydryl groups. Archives of Biochemistry and Biophysics 82(1): 70-77.

Helen, A.K., Krishnakumar, P.L., Vijayammal \& Augusti, K.T. 2000. Antioxidant effect of onion oil (Allium cepa. Linn) on the damages induced by nicotine in rats as compared to alpha-tocopherol. Toxicology Letters 116: 61-68.

Hirunpanich, V., Utaipat, A., Morales, N.P., Bunyapraphatsara, N., Sato, H., Herunsale, A. \& Suthisisang, C. 2006. Hypocholesterolemic and antioxidant effects of aqueous extracts from the dried calyx of Hibiscus sabdariffa L. in hypercholesterolemic rats. Journal of Ethnopharmacology 103: 252-260.

Idris, M.H.M., Siti, B.B., Mohamad, O. \& Jamaludin, M. 2012. Protective role of Hibiscus sabdariffa calyx extract against streptozotocin induced sperm damage in diabetic rats. EXCLI Journal 11: 659-669.

Lado-Abeal, J. \& Norman, R.L. 2002. Leptin and reproductive function in males. Seminar Reproduction Medicine 20: $145-152$.

Lin, T-L., Lin, H-H., Chen, C-C., Lin, M-C., Chou, M-C. \& Wang, C-J. 2007. Hibiscus sabdariffa extract reduced serum cholesterol in men and women. Nutrition Research 27(3): 140-145.

Mahaneem, M., Siti,A.S., Hasnan, J. \& Kuttulebbai, N.S.S. 2011. Antioxidant protective effect of honey in cigarette smokeinduced testicular damage in rats. International Journal of Molecular Science 12: 5508-5521.

Mohamed, A., Sulaiman, S.A., Jaafar, H. \& Sirajudeen, K.N.S. 2012. Effect of different doses of Malaysian honey on reproductive parameters in adult male rats. Andrologia 44: 182-186.

Mosbah, R., Yousef, M.I. \& Mantovani, A. 2015. Nicotineinduced reproductive toxicity, oxidative damage, histological changes and haematotoxicity in male rats: The protective effects of green tea extract. Experimental and Toxicologic Pathology 67: 253-259.

Mozaffari-Khosravi, Jalali-Khanabadi, B.A., Afkhami-Ardekani, M., Fatehi, F. \& Noori-Shadkam, M. 2009. The effects of sour tea (Hibiscus sabdariffa) on hypertension in patients with type II diabetes. Journal of Human Hypertension 23: 48-54.

Olusola, A.O. \& Adekunle, A. 2011. Evaluation of the antioxidant effects of Hibiscus sabdariffa Calyx extracts on 2, 4-Dinitrophenylhydrazine-induced oxidative damage in rabbits. Department of Biochemistry, Nigeria. pp. 1-11.

Polyzos, A., Schmid, T.E., Pina-Guzman, B., Quintanilla-Vega, B. \& Marchetti,F. 2009. Differential sensitivity of male germ cells to mainstream ans sidestream tobacco smoke in the mouse. Food Chemical Toxicology 237(3): 298-305.

Ross, I.A. 1999. Hibiscus sabdariffa in Medicinal Plants of the World. New Jersey: Human Press. 1: 165.
Steinman, N., Gamzu, R., Yogev, L., Botchan, A., Schreiber, L. \& Yavetz, H. 2001. Serum leptin concentrations are higher in azoospermic than in normozoospermic men. Fertility and Sterility 75: 821-822.

Stocks, J. \& Dormandy, T.L. 1971. The autooxidation of human red cell lipids induced by hydrogen peroxide. Journal of Hematology 20: 95-111.

Syazana, M.S.N., Halim, A.S., Gan, S.H. \& Shamsuddin, S. 2011. Antiproliferative effect of methanolic extraction of tualang honey on human keloid fibroblasts. BMC Complementary Alternative Medicine 11(1): 82.

Toklu, H., Sehirli, O., Sahin, H., Centinel, S., Yegen, B.C. \& Sener, G. 2010. Resveratrol supplementation protects against chronic nicotine-induced oxidative damaged and organ dysfunction in the rat urogenital system. Marmara Pharmaceutical Journal. 14(1): 29-40.

Trummer, H., Haberman, H., Haas, J. \& Pummer, K. 2002. The impact of cigarette smoking on human semen parameters and hormones. Human Reproduction 17: 1554-1559.

Tundulawessa, Y., Yongchaiyud, P., Chutrthong, W. \& Tundulawessa, K. 2010. The bioequivalent and effect of nicotine formulation gum on smoking cessation. Journal of the Medical Association of Thailand 93(5): 574-579.

WHO. 2010a. Warning, the Tobacco Industry is Targeting Women. World no Tobacco. Geneva: WHO Press.

WHO. 2010b. WHO Laboratory Manual for the Examination and Processing of Human Semen. Ed. ke-5. Geneva: WHO Press.

Wong, W.Y., Thomas, C.M., Merkus, H.M., Zielhuis, G.A., Doesburg, W.H. \& Steegers-Theunissen, R.P. 2000. Cigarette smoking and the risk of male factor subfertility: Minor association between cotinine in seminal plasma and semen morphology. Fertility and Sterility 74: 930-935.

Zhang, J.P., Meng, Q.Y., Zhang, L.J., Mao, Y.L. \& Sun, Z.X. 2000. Effect of smoking on semen quality of infertile men in Shandong, China. Asian Journal of Andrology 2: 143-146.

Program Sains Bioperubatan

Pusat Pengajian Sains Diagnostik dan Kesihatan Gunaan

Fakulti Sains Kesihatan

Universiti Kebangsaan Malaysia

Jalan Raja Muda Abd Aziz

50300 Kuala Lumpur, Wilayah Persekutuan

Malaysia

*Pengarang untuk surat-menyurat; email: balkis@ukm.edu.my

Diserahkan: 14 Julai 2016

Diterima: 20 April 2017 